\title{
Kebolehserapan Metilena Biru oleh Hidrogel Selulosa Bakteria Teradiasi Gamma menggunakan Isoterma Langmuir dan Freundlich
}

(Absorption Ability of Gamma Irridiated Bacterial Cellulose Hydrogel using Langmuir and Freundlich Isotherme)

\author{
AZWAN Mat LaZIM*, Adil HaKam OSMan \& MARYAM MOKHTAROM
}

ABSTRAK

\begin{abstract}
Kajian ini bertujuan menghasilkan hidrogel responsif berasaskan selulosa bakteria yang diperoleh daripada Nata de Coco (NDC) dan asid akrilik (AA). Tiga jenis sampel telah disediakan berdasarkan nisbah NDC:AA iaitu sampel hidrogel A [1:1], B [2:1] dan C [3:1]. Pencangkukan AA terhadap molekul NDC menggunakan kaedah pempolimeran radikal Gamma (GRP) menghasilkan hidrogel NDC-AA (sumber: ${ }^{60} \mathrm{Co}$ ). Kaedah yang menggunakan tenaga yang tinggi ini akan menghasilkan radikal bebas seperti $\mathrm{OH} \bullet, \mathrm{H}_{\bullet}, \mathrm{H}_{2} \mathrm{O}_{2}$ dan $\mathrm{H}_{2}$. Kesemua radikal ini menyerang kumpulan berfungsi yang terdapat pada NDC dan AA seterusnya menggalakkan proses pencangkukan AA terhadap NDC. Hidrogel B [2:1] dipilih dan diuji sebagai penjerap metilena biru $(M B)$ dan perubahan keamatannya telah dianalisis menggunakan spektrofotometer UV-VIS. Keputusan yang diperoleh telah diselaraskan dengan dua model isoterma, Langmuir dan Freundlich. Perbandingan pemalar bagi kedua-dua model isoterma ini mendapati hidrogel B [2:1] yang dihasilkan telah mematuhi kedua-dua model isoterma. Keputusan yang diperoleh ini menyokong keupayaan hidrogel B [2:1] untuk digunakan sebagai penjerap alternatif MB yang paling efisien.
\end{abstract}

Kata kunci: Hidrogel; metilena biru; penjerapan; selulosa bakteria; teknik sinaran gamma

\section{ABSTRACT}

This study aimed to produce a responsive hydrogel based on bacterial cellulose obtained from Nata de Coco (NDC) and acrylic acid (AA). Three samples were prepared by ratio of NDC:AA and labelled as hydrogel A [1:1], B [2:1] and $C$ [3:1]. The grafting of AA onto NDC molecules using gamma radiation polymerisation (GRP) method resulting in the formation of NDC-AA hydrogel (source: ${ }^{60} \mathrm{Co}$ ). The high energy used in this method produced free radicals such as $\mathrm{OH} \bullet$ $\mathrm{H} \cdot \mathrm{H}_{2} \mathrm{O}_{2}$ and $\mathrm{H}_{2}$. These free radicals attacked the functional groups of NDC and AA, allowing AA to be grafted onto NDC. Hydrogel B [2:1] was selected for further test in methylene blue (MB) adsorption using UV-VIS spectrophotometer. All data were analyzed and adjusted according to Langmuir and Freundlich isotherm model. The comparison of constant in both samples were analyzed and found that hydrogel $B$ [2:1] data has fitted both models. Therefore, the results obtained supported the ability of hydrogel $B$ [2:1] as an alternative MB adsorbent.

Keywords: Adsorption; bacterial cellulose; gamma radiation technique; hydrogel; methylene blue

\section{INTRODUCTION}

Penyelidikan yang berkaitan dengan hidrogel telah wujud sejak tahun 1894 (Lee et al. 2013). Namun begitu, hidrogel pada ketika itu dijelaskan sebagai garam tak-organik gel koloid yang mana berbeza dengan hidrogel pada hari ini. Hidrogel ditakrifkan sebagai jaringan polimer atau kopolimer tiga-dimensi yang dapat mengekal atau memegang molekul air sebanyak 30\%. Jaringan polimer hidrogel yang terbentuk terdiri daripada hasil silang paut yang dihasilkan secara fizikal atau kimia, bergantung kepada kaedah pempolimeran yang digunakan (Ashri \& Lazim 2014; Azman et al. 2016; Boo \& Azwan 2016). Struktur hidrogel terbina daripada kumpulan berfungsi hidrofilik seperti $-\mathrm{OH},-\mathrm{COOH},-\mathrm{NH}_{2},-\mathrm{CONH}_{2}$ dan $\mathrm{SO}_{3} \mathrm{H}$ atau jaringan polimer yang terhidrat dalam keadaan akues (Hadi \& Idayu 2012).
Kebanyakan hidrogel yang dikaji adalah berasaskan polimer sintetik. Umumnya, hidrogel yang berasaskan polimer sintetik ini berupaya mengekalkan kapasiti molekul air yang tinggi kerana hidrogel mempunyai keporosan yang tinggi (Liew et al. 2015). Namun begitu, menurut Ashri dan Lazim (2014) dan Azman et al. (2016), hidrogel jenis ini mempunyai kelemahan tersendiri, iaitu kekuatan fizikal yang rendah dan tidak dapat menampung tekanan yang tinggi. Selain itu, Mohamad et al. (2014) menyatakan bahawa kekuatan fizikal hidrogel yang berasaskan polimer sintetik adalah bergantung kepada darjah silang-taut antara monomer yang terlibat dan komposisi monomer yang digunakan. Menurutnya lagi, penghasilan hidrogel tersebut perlu menggunakan kaedah konvensional iaitu kaedah pempolimeran radikal bebas yang mana melibatkan bahan kimia tambahan seperti 
agen pemula dan agen penyilang-taut. Penggunaan bahan tambahan ini adalah berbahaya dan memerlukan proses yang rumit untuk diasingkan daripada jaringan hidrogel yang telah disintesis (Amin et al. 2012). Oleh yang demikian, pendekatan fizikal dengan menggunakan tenaga tinggi seperti kaedah gelombang mikro, sinaran elekton dan gamma menjadi alternatif dalam penghasilan hidrogel. Selain menjimatkan masa, kaedah ini turut mengurangkan penggunaan bahan kimia yang berbahaya.

Pewarna kationik memberikan impak yang negatif kepada alam sekitar sekiranya tidak diurus dan dirawat terlebih dahulu sebelum dilepaskan ke dalam air. Sesetengah pewarna kationik bukan sahaja bersifat karsinogenik malah boleh memudaratkan hidupan aquatik dengan mengganggu rantaian makanan hidupan tersebut (Sajab et al. 2013). Salah satu kaedah bagi menangani masalah ini adalah dengan memanfaatkan hidrogel yang terdiri daripada jaringan polimer 3-dimensi sebagai penjerap poros yang baik (Azwan et al. 2013). Kajian yang dilakukan oleh Zhou et al. (2011) mendapati bahawa hidrogel merupakan penjerap pewarna kationik yang lebih baik berbanding kaedah konvensional seperti penggunaan membran dan penjerapan ke atas karbon teraktif.

Dalam kajian ini modifikasi telah dilakukan ke atas selulosa yang diekstrak daripada Nata de Coco (NDC) yang dicangkukkan ke atas asid akrilik (AA) supaya dapat bertindak sebagai matriks hidrogel yang responsif ke atas sebarang ransangan $\mathrm{pH}$. Memandangkan tiada kajian sintesis hidrogel berasaskan Nata de Coco menggunakan kaedah sinaran gamma, maka kaedah sinaran gamma dijadikan sebagai fokus alternatif dalam penghasilan hidrogel. Selain itu, keupayaan penjerapan metilena biru (MB) oleh hidrogel berasaskan NDC turut dikaji dengan menggunakan model isoterma Langmuir dan Freundlich.

\section{BAHAN DAN KAEDAH}

\section{SINTESIS HIDROGEL NDC-C-PAA}

Penyediaan serbuk selulosa bakteria daripada NDC dilakukan berdasarkan kepada kajian yang telah dijalankan oleh Amin et al. (2014). Sebanyak 322 g serbuk NDC dicampurkan bersama-sama dengan $5 \mathrm{~g}$ asid sulfurik $(2.0 \mathrm{M})$ ke dalam kelalang kon menghasilkan campuran $65 \%(\mathrm{w} / \mathrm{w})$. Campuran ini dikacau sehingga homogen. Selepas itu, campuran itu dibasuh dengan menggunakan air ternyah ion untuk menjadikan serbuk NDC dalam keadaan neutral ( $\mathrm{pH} 7$ ) sebelum diasingkan dengan menggunakan mesin pengempar (4500 rpm, $10 \mathrm{~min}$ ). Serbuk NDC kemudiannya dituras dan dikeringkan. Sebanyak $2.6 \mathrm{~g}$ serbuk halus NDC diserakkan di dalam $250 \mathrm{~mL}$ air suling untuk menjadikan campuran $1 \%$ (w/v).

Untuk menghasilkan hidrogel, sebanyak $10 \mathrm{~mL}$ NDC (1\%) dicampurkan dengan $10 \mathrm{~mL}$ asid akrilik (AA) dan campuran ini kemudiannya dikacau menggunakan alat penghomogen (IKA ${ }^{\circledR}$ RW 20 Digital, India) selama 2 jam. Nisbah bagi campuran NDC:AA ialah [1:1], [2:1] dan [3:1]. Campuran kemudiannya dimasukkan ke dalam piring petri plastik dan ditutup dengan menggunakan parafilem sebelum didedahkan kepada sinaran gamma pada dos 30 kGy (Cell 220 Excel, MDS Nordian, Canada).

\section{UJIAN PENJERAPAN METILENA BIRU (MB) OLEH HIDROGEL MENGGUNAKAN SPEKTROFOTOMETER ULTRALEMBAYUNG/CAHAYA NAMPAK (UV/VIS)}

Ujian penjerapan MB dijalankan menggunakan jerapan spekstroskopi ultralembayung-cahaya nampak (UV/ VIS) menggunakan instrumen Spektrophotometer Ultralembayung/Nampak (UV-1800, Shimadzu, Japan).

\section{Analisis kinetik}

Analisis ini dijalankan dengan menggunakan hidrogel dengan berat yang malar (0.05 g). Manakala kepekatan larutan MB digunakan ialah 2.0, 4.0, 6.0, 8.0 dan $10.0 \mathrm{mg} / \mathrm{L}$.

Jerapan MB pada panjang gelombang $664 \mathrm{~nm}$ diukur menggunakan Sinaran UltraViolet-Cahaya Nampak (SUV$\mathrm{CN}$ ) yang diambil setiap sejam selama 5 jam dan diulang sebanyak tiga kali bagi mendapatkan data yang persis dan jitu. Jumlah kepekatan MB yang dijerap oleh kesemua hidrogel pada keseimbangan $\left(q_{\mathrm{e}}\right)$ diketahui dengan menggunakan pengiraan (1):

$$
q_{\mathrm{e}}=\frac{\left(C_{\mathrm{o}}-C_{\mathrm{e}}\right) V}{W}
$$

dengan $C_{\mathrm{o}}$ dan $C_{\mathrm{e}}(\mathrm{mg} / \mathrm{L})$ merupakan kepekatan awal dan kepekatan pada keseimbangan; $V$ (l) merupakan isi padu MB yang digunakan; dan $W$ (g) adalah berat awal hidrogel sebelum jerapan. Unit bagi $q_{\mathrm{e}}$ adalah (mg/g). Jumlah kepekatan MB yang dijerap oleh kesemua hidrogel pada masa yang ditetapkan $\left(q_{t}\right)$ dapat diketahui dengan menggunakan (2):

$$
q_{\mathrm{e}}=\frac{\left(C_{\mathrm{o}}-C_{\mathrm{t}}\right) V}{W}
$$

dengan $C_{\mathrm{o}}$ dan $C_{\mathrm{t}}(\mathrm{mg} / \mathrm{L})$ merupakan kepekatan awal dan kepekatan pada masa yang ditetapkan, $V$ (1) merupakan isi padu MB yang digunakan; dan $W(\mathrm{~g})$ adalah berat awal hidrogel sebelum jerapan. Unit bagi $q_{\mathrm{t}}$ adalah $(\mathrm{mg} / \mathrm{g})$.

Model isoterma Langmuir dan model isoterma Freundlich Data uji kaji bagi jerapan isoterma bagi kedua-dua model isoterma (Langmuir dan Freundlich) diperoleh daripada jumlah jerapan MB pada keseimbangan pada kepekatan MB yang berbeza (2.0-10.0 mg/L). Data ini dianalisis menggunakan model isoterma Langmuir berdasarkan (3):

$$
\frac{C_{\mathrm{e}}}{q_{\mathrm{e}}}=\frac{1}{b q_{\mathrm{m}}}+\frac{C_{\mathrm{e}}}{q_{\mathrm{m}}}
$$

Manakala data yang dianalisis menggunakan model isoterma Freundlich pula menggunakan (4):

$$
g_{\mathrm{e}}=k_{\mathrm{f}} C_{\mathrm{e}}^{\frac{1}{\mathrm{n}}}
$$

dengan $q_{\mathrm{e}}(\mathrm{mg} / \mathrm{g})$ adalah jumlah keseimbangan MB pada kepekatan awal yang berbeza; $q_{\mathrm{m}}(\mathrm{mg} / \mathrm{g})$ dan $b(\mathrm{l} / \mathrm{mg})$ merupakan pekali isoterma Langmuir; $q_{\mathrm{m}}$ mewakili jumlah maksimum MB yang dijerap oleh sampel hydrogel; $k_{\mathrm{f}}\left(\mathrm{mg}^{(\mathrm{n}-1) / \mathrm{n}} \cdot \mathrm{g}^{-1} \mathrm{l}^{1 / \mathrm{n}}\right)$ dan $\mathrm{n}$ merupakan konstan isoterma 
Freundlich; $k_{\mathrm{f}}$ juga dikenali sebagai kapasiti jerapan manakala $1 / n$ juga dikenali sebagai keamatan jerapan (Ghaedi et al. 2014; Ofomaja 2007).

\section{KEPUTUSAN DAN PERBINCANGAN}

\section{KEPUTUSAN KESAN PENJERAPAN PELBAGAI HIDROGEL KE ATAS KEPEKATAN MB BERBANDING MASA}

Kesan penjerapan ke atas hidrogel $\mathrm{A}[1: 1]$, hidrogel $\mathrm{B}[2: 1]$ dan hidrogel C[3:1] dijalankan untuk mengkaji keupayaan hidrogel menyerap MB pada masa yang telah ditetapkan, iaitu selama $360 \mathrm{~min}$. Kepekatan awal MB juga telah ditetapkan iaitu $6.0 \mathrm{mg} / \mathrm{L}$. Rajah 1 menunjukkan graf jumlah jerapan pada masa $t$, manakala $q_{\mathrm{t}}(\mathrm{mg} / \mathrm{g})$ ialah MB yang telah dijerap oleh ketiga-tiga hidrogel. Jumlah jerapan MB $\left(q_{t}\right)$ pada masa 60 min yang dijerap oleh hidrogel A [1:1], hidrogel B [2:1] dan hidrogel C [3:1] ialah sebanyak 450,470 dan $450 \mathrm{mg} / \mathrm{L}$, manakala jumlah jerapan MB $\left(q_{t}\right)$ dari masa $120 \mathrm{~min}$ hingga $360 \mathrm{~min}$ bagi ketiga-tiga hidrogel masing-masing antara 480-510 mg/L, 470-540 mg/L dan 450-460 mg/L.

Berdasarkan graf pada Rajah 1, perubahan jumlah jerapan MB $\left(q_{t}\right)$ selepas 120 min tidak menunjukkan perubahan yang besar berbanding jumlah jerapan MB $\left(q_{t}\right)$ dari 0 hingga $60 \mathrm{~min}$. Secara umumnya, jumlah jerapan MB $\left(q_{t}\right)$ oleh hidrogel adalah berkadar langsung dengan masa. Pada masa tertentu, $\left(q_{t}\right)$ akan mencapai nilai yang menghampiri malar. Hal ini kerana kepekatan MB yang dijerap oleh hidrogel mencapai kapasiti yang maksimum. Pada masa ini juga, $\left(q_{t}\right)$ dikatakan mencapai keseimbangan dinamik. Keseimbangan dinamik ialah keseimbangan yang dicapai setelah $\left(q_{t}\right)$ adalah sama dengan jumlah kepekatan MB dalam larutan atau luar daripada jaringan hidrogel seperti yang dilaporkan oleh Hameed et al. (2007). Masa yang diambil oleh hidrogel untuk mencapai keseimbangan dinamik ini pula dikenali sebagai masa keseimbangan dan masa keseimbangan yang direkodkan bagi hidrogel dalam kajian ini adalah $120 \mathrm{~min}$.

Ketiga-tiga hidrogel berkeupayaan menyerap MB kerana kumpulan berfungsi karboksil yang terdapat pada rantaian poliakrilik telah bertindak sebagai tapak ikatan kation MB (Zhou et al. 2011). Rajah 2 memberi gambaran bagaimana interaksi antara jaringan hidrogel dan molekul MB berlaku. Perbandingan penjerapan MB antara kesemua hidrogel juga turut dilakukan dan hasilnya hidrogel $\mathrm{B}[2: 1]$ mempunyai jumlah jerapan MB lebih tinggi berbanding hidrogel yang lain. Oleh itu, hidrogel B[2:1] dipilih untuk digunakan sebagai sampel penjerap bagi analisis yang seterusnya iaitu penjerapan isoterma model Langmuir dan model Freundlich bagi MB (Dafader et al. 2012; Hameed et al. 2007; Ofomaja 2007; Zhou et al. 2011).

KEPUTUSAN KESAN PENJERAPAN HIDROGEL B [2:1] KE ATAS PELBAGAI KEPEKATAN MB PADA MASA TERTENTU

Kesan penjerapan hidrogel B [2:1] ke atas pelbagai kepekatan MB (julat kepekatan antara 2.0 hingga $6.0 \mathrm{mg} / \mathrm{L}$ )

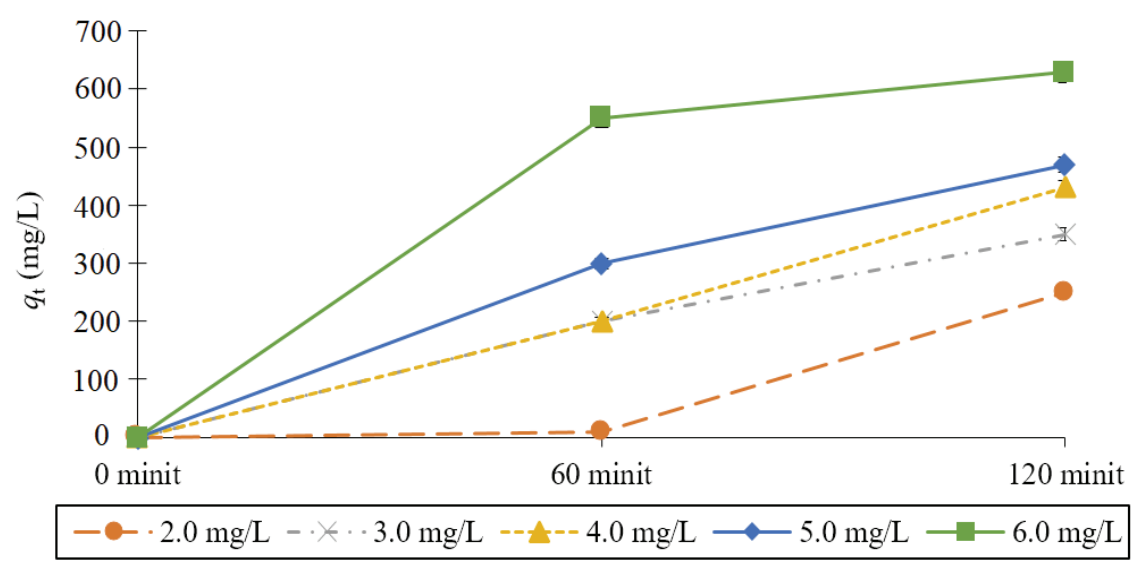

RAJAH 1. Graf jumlah jerapan $\mathrm{MB}, q_{\mathrm{t}}(\mathrm{mg} / \mathrm{g})$ melawan masa, $t(\mathrm{~min})$ bagi hidrogel A [1:1], hidrogel B [2:1] dan hidrogel C [3:1]

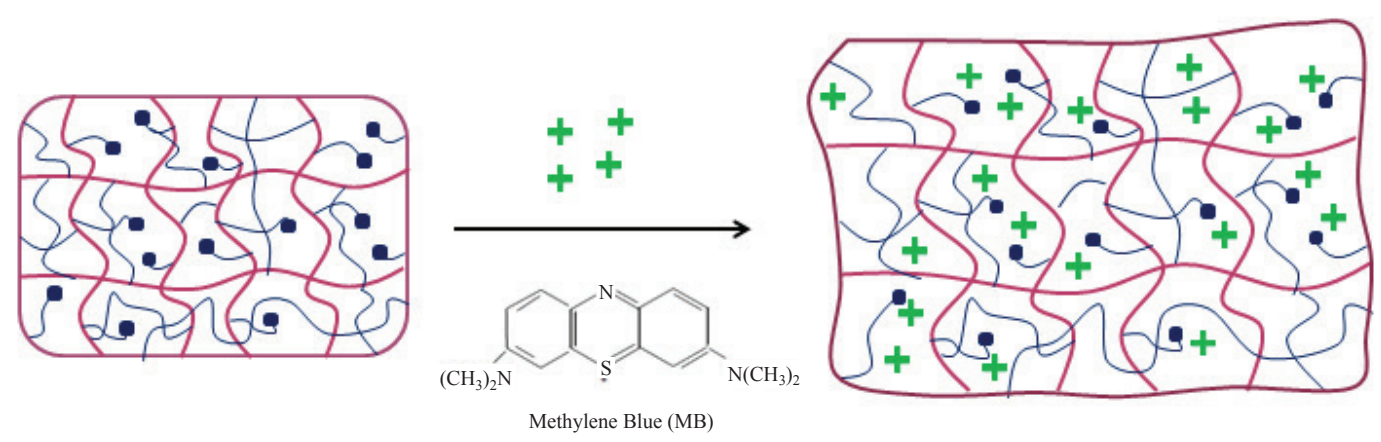

RAJAH 2. Interaksi antara jaringan hidrogel dan molekul MB 


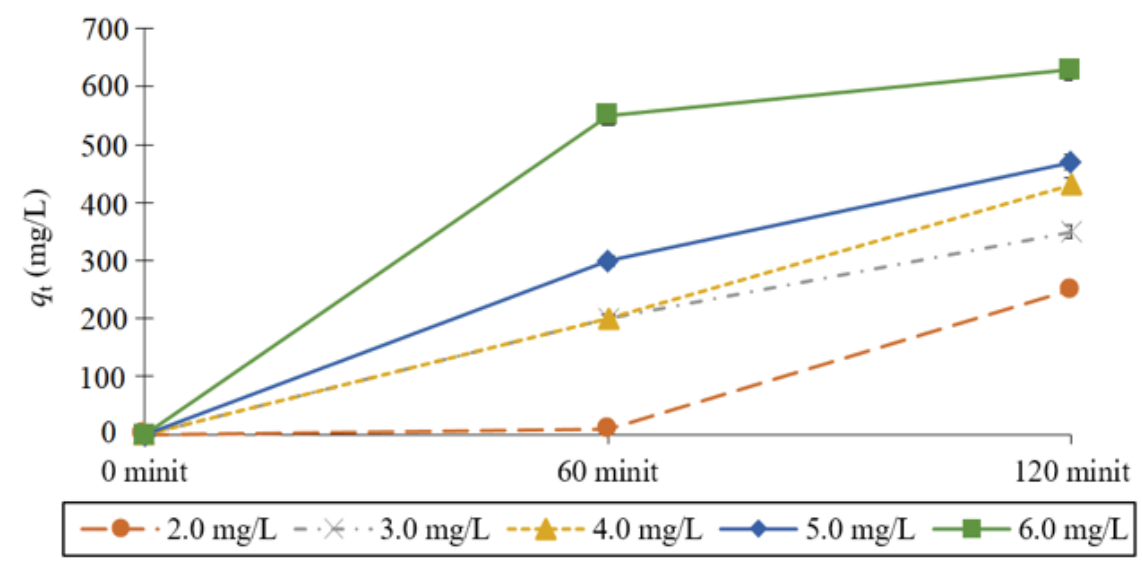

RAJAH 3. Graf jumlah penjerapan $\mathrm{MB}, q_{\mathrm{t}}(\mathrm{mg} / \mathrm{g})$ melawan masa, $t(\mathrm{~min})$ oleh hidrogel dengan kepekatan MB yang berbeza

dijalankan selama 120 min. Rajah 3 menunjukkan graf jumlah penjerapan pada suatu tempoh masa, $\left(q_{t}\right)$ melawan masa dengan kepekatan MB yang berlainan. Berdasarkan graf ini, kapasiti penjerapan yang dicapai oleh hidrogel B [2:1] meningkat daripada 10 hingga $550 \mathrm{mg} / \mathrm{L}$ dengan peningkatan kepekatan awal MB daripada 200 hingga 600 $\mathrm{mg} / \mathrm{L}$ selepas $60 \mathrm{~min}$.

Selepas $120 \mathrm{~min}$, kapasiti penjerapan yang dicapai oleh hidrogel ini turut meningkat daripada 250 hingga 630 $\mathrm{mg} / \mathrm{L}$ dengan peningkatan kepekatan awal MB daripada 2.0 hingga $6.0 \mathrm{mg} / \mathrm{L}$. Hal ini membuktikan bahawa jumlah tapak jerapan (kumpulan berfungsi karboksil) yang terdapat pada jaringan hidrogel B [2:1] yang terikat dengan molekul MB adalah rendah dalam larutan MB berkepekatan rendah. Pada larutan MB berkepekatan tinggi pula, jumlah molekul MB adalah tinggi dan tapak jerapan ini akan terikat sepenuhnya dengan molekul MB sehingga mencapai kapasiti penjerapan maksimum oleh hidrogel B [2:1] (Sun et al. 2015).
KEPUTUSAN JERAPAN KINETIK: MODEL KINETIK TERTIB PERTAMA PSEUDO DAN KINETIK TERTIB PSEUDO KEDUA

Pemalar kadar jerapan oleh hidrogel A [1:1], hidrogel B [2:1] dan hidrogel C [3:1] diperoleh daripada model kinetik tertib pertama pseudo dan model kinetik tertib pseudo kedua (Azizian 2004; Azizian \& Fallah 2010; Ghaedi et al. 2014; Haerifar \& Azizian 2013). Model kinetik tertib pseudo pertama ditunjukkan seperti (5):

$$
\ln \left(q_{\mathrm{e}}-q_{\mathrm{t}}\right)=\ln q_{\mathrm{e}}-K_{1} t
$$

dengan $q_{\mathrm{e}}$ dan $q_{\mathrm{t}}$ adalah jumlah MB (mg/g) yang dijerap pada keseimbangan dan jumlah MB $(\mathrm{mg} / \mathrm{g})$ yang dijerap oleh hidrogel pada masa tertentu, $t$ (jam). Nilai $K_{1}\left(\mathrm{jam}^{-1}\right)$ adalah pemalar kadar penjerapan bagi model kinetik tertib pertama pseudo boleh diperoleh daripada graf $\ln \left(q_{\mathrm{e}}-q_{\mathrm{t}}\right)$ melawan $t$. Rajah 4 menunjukkan graf model kinetik tertib pertama pseudo bagi kesemua hidrogel yang dikaji (Azizian 2004; Hameed et al. 2007).

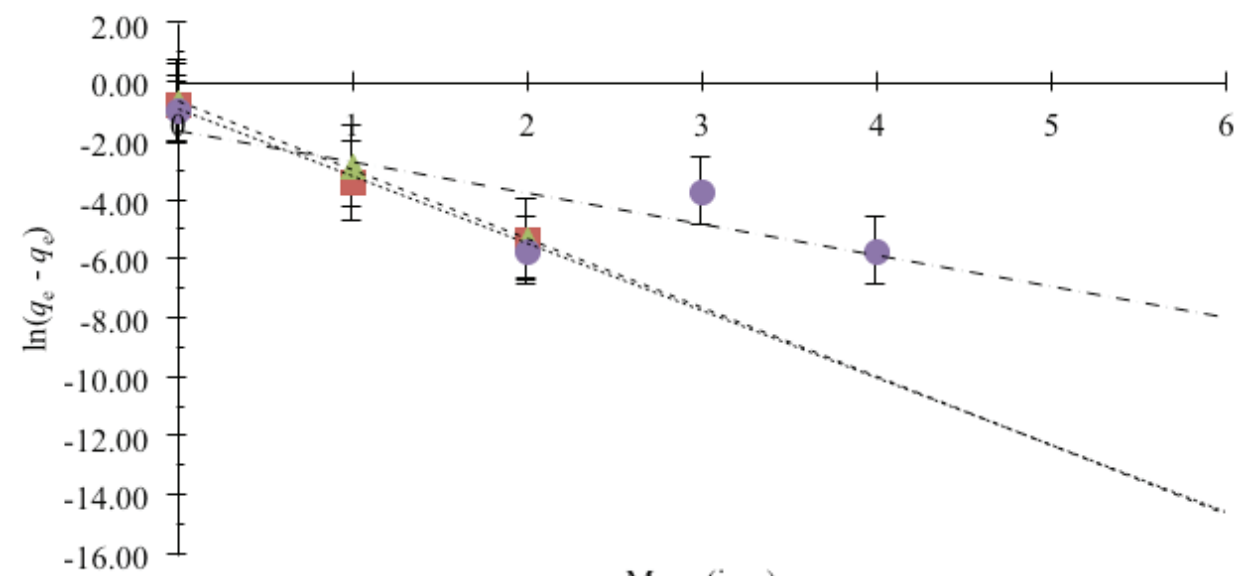

Masa (jam)

\begin{tabular}{|c|c|c|}
\hline & Hidrogel A[1:1] & $\Delta \quad$ Hidrogel B[2:1] \\
\hline - & Hidrogel C[3:1] & $\cdots \cdots \cdots \cdots$ Linear (Hidrogel A[1:1]) \\
\hline$\cdots+. .10$ & Linear (Hidrogel B[2:1]) & $\ldots-$ Linear (Hidrogel C $[3: 1]$ ) \\
\hline
\end{tabular}

RAJAH 4. Graf model kinetik tertib pertama pseudo bagi hidrogel A [1:1], hidrogel B [2:1] dan hidrogel C [3:1] 
Model kinetik tertib kedua pseudo ditunjukkan seperti (6):

$$
\frac{t}{q_{\mathrm{e}}}=\frac{1}{K_{2} q_{\mathrm{e}}^{2}}+\frac{1}{q_{\mathrm{e}}} t
$$

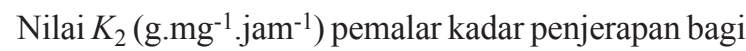
model kinetik tertib kedua pseudo boleh diperoleh daripada graf $t / q_{\mathrm{e}}$ melawan masa, $t$ (jam) (Azizian 2004; Zhou et al. 2013). Rajah 5 menunjukkan graf model kinetik tertib kedua pseudo bagi kesemua hidrogel yang dikaji. Jadual 1 menunjukkan kesemua pemalar bagi model kinetik tertib pertama pseudo dan model kinetik tertib kedua pseudo bagi hidrogel A [1:1], hidrogel B [2:1] dan hidrogel C [3:1].

Walaupun $R^{2}$ yang diperoleh daripada graf pada Rajah 4 bagi ketiga-tiga hidrogel mempunyai nilai yang persis kepada nilai 1, nilai $q_{\mathrm{e}}$ yang diperoleh daripada kajian ini tidak persis kepada nilai $q_{\mathrm{e}}$ yang diperoleh daripada graf yang diplot. Oleh itu, jerapan MB oleh ketiga-tiga hidrogel tidak sesuai ditakrifkan sebagai kinetik tertib pertama pseudo. Namun begitu, $R^{2}$ yang diperoleh daripada graf pada Rajah 5 bagi ketiga-tiga hidrogel juga menunjukkan persis kepada nilai 1 . Nilai $R^{2}$ bagi hidrogel B [2:1] merupakan nilai $R^{2}$ yang paling persis kepada nilai 1 (0.9992) berbanding nilai $R^{2}$ bagi hidrogel $\mathrm{A}[1: 1]$ dan hidrogel $\mathrm{C}[3: 1]$.

Nilai $q_{\mathrm{e}}$ yang diperoleh daripada graf pada Rajah 5 pula persis kepada nilai $q_{\mathrm{e}}$ yang diperoleh daripada kajian ini. Di samping itu, hidrogel B[2:1] mempunyai nilai $q_{\mathrm{e}}$ yang paling persis kepada nilai $q_{\mathrm{e}}$ yang diperoleh daripada kajian ini. Kesimpulannya, ketiga-tiga hidrogel mempunyai jerapan MB yang ditakrifkan sebagai kinetik tertib kedua pseudo dan hidrogel $\mathrm{B}[2: 1]$ menunjukkan prestasi jerapan MB yang paling baik berbanding hidrogel $\mathrm{A}[1: 1]$ dan hidrogel $\mathrm{C}[3: 1]$. Perbandingan keputusan yang diperoleh bagi pemalar model kinetik tertib pertama pseudo dan model kinetik tertib kedua pseudo bagi hidrogel $\mathrm{A}[1: 1]$, hidrogel $\mathrm{B}[2: 1]$ dan hidrogel $\mathrm{C}[3: 1]$ ditunjukkan dalam Jadual 1.

\section{KEPUTUSAN JERAPAN ISOTERMA: MODEL ISOTERMA LANGMUIR DAN MODEL ISOTERMA FREUNDLICH}

Jerapan isoterma menerangkan bagaimana jerapan molekul yang tersebar antara fasa cecair dan fasa pepejal apabila proses penjerapan telah mencapai keseimbangan (Hameed et al. 2007). Data isoterma yang diperoleh daripada analisis ini adalah penting untuk disesuaikan dengan mana-mana model isoterma yang sesuai untuk diaplikasikan dalam pelbagai bidang pada masa hadapan. Rajah 6 dan 7 masingmasing menunjukkan graf bagi dua model jerapan isoterma iaitu model Langmuir dan Freundlich yang digunakan dalam kajian ini untuk mengkaji penjerapan MB oleh hidrogel $\mathrm{B}[2: 1]$.

Model isoterma Langmuir digambarkan sebagai jerapan berbentuk mono-lapisan pada permukaan homogen yang terdapat pada bahan penyerap. Model

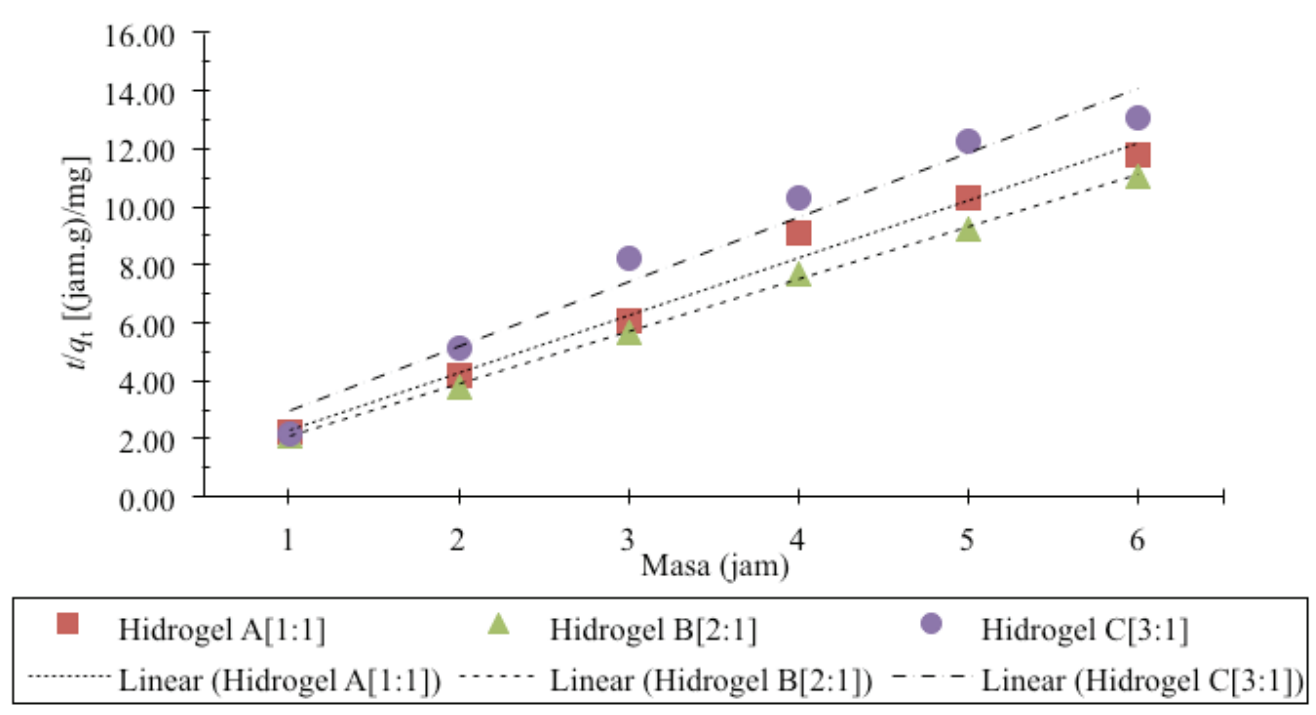

RAJAH 5. Graf model kinetik tertib kedua pseudo bagi hidrogel A [1:1], hidrogel B [2:1] dan hidrogel C [3:1]

JADUAL 1. Perbandingan pemalar model kinetik tertib pertama pseudo dan model kinetik tertib kedua pseudo bagi hidrogel A [1:1], hidrogel B [2:1] dan hidrogel C [3:1]

\begin{tabular}{|c|c|c|c|c|c|c|c|}
\hline \multirow[b]{2}{*}{ Hidrogel } & \multirow{2}{*}{$\begin{array}{c}\text { Jumlah } \\
\text { kepekatan pada } \\
\text { keseimbangan, } \\
q_{\mathrm{e}},(\mathrm{mg} / \mathrm{g})\end{array}$} & \multicolumn{3}{|c|}{ Kinetik tertib pertama pseudo } & \multicolumn{3}{|c|}{ Kinetik tertib kedua pseudo } \\
\hline & & $\begin{array}{l}\text { Pemalar kadar } \\
\text { jerapan, } K_{1} \\
\quad\left(\text { jam }^{-1}\right)\end{array}$ & $\begin{array}{c}\text { Jumlah kepekatan pada } \\
\text { kesimbangan (graf) } \\
q_{\mathrm{e}}(\mathrm{mg} / \mathrm{g})\end{array}$ & $R^{2}$ & $\begin{array}{l}\text { Pemalar kadar } \\
\text { jerapan, } \\
K_{2}(\mathrm{~g} / \mathrm{mg} . j \mathrm{jam})\end{array}$ & $\begin{array}{c}\text { Jumlah kepekatan pada } \\
\text { kesimbangan (graf) } \\
q_{\mathrm{e}}(\mathrm{mg} / \mathrm{g})\end{array}$ & $R^{2}$ \\
\hline $\mathrm{A}[1: 1]$ & 0.48 & 2.28 & 4.20 & 0.99 & 10.20 & 0.51 & 0.99 \\
\hline $\mathrm{B}[2: 1]$ & 0.53 & 2.33 & 5.47 & 0.99 & 10.94 & 0.55 & 0.99 \\
\hline $\mathrm{C}[3: 1]$ & 0.39 & 1.05 & 0.35 & 0.63 & 6.43 & 0.45 & 0.97 \\
\hline
\end{tabular}




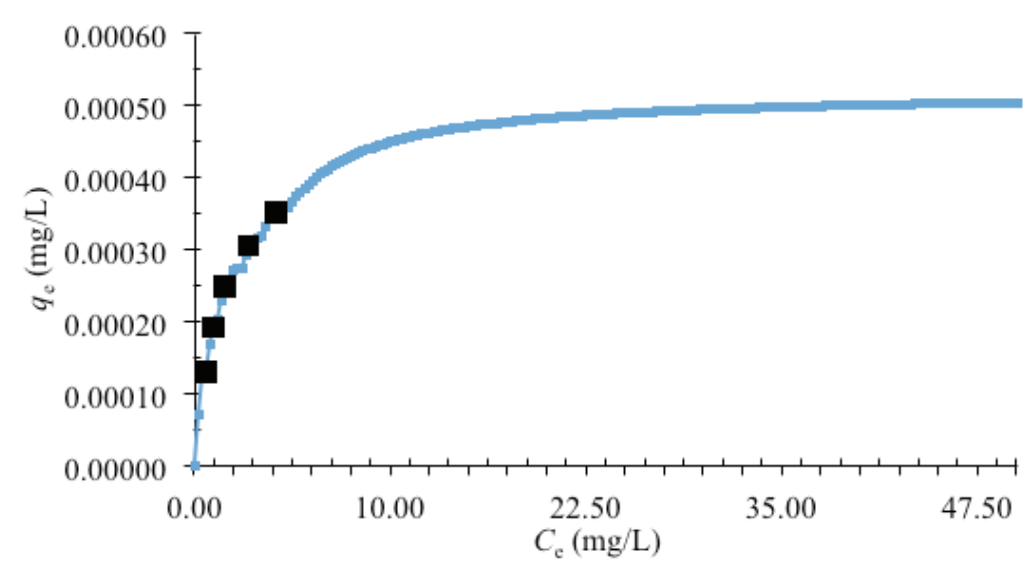

RAJAH 6. Graf model isoterma Langmuir bagi penjerapan MB oleh hidrogel B [2:1]

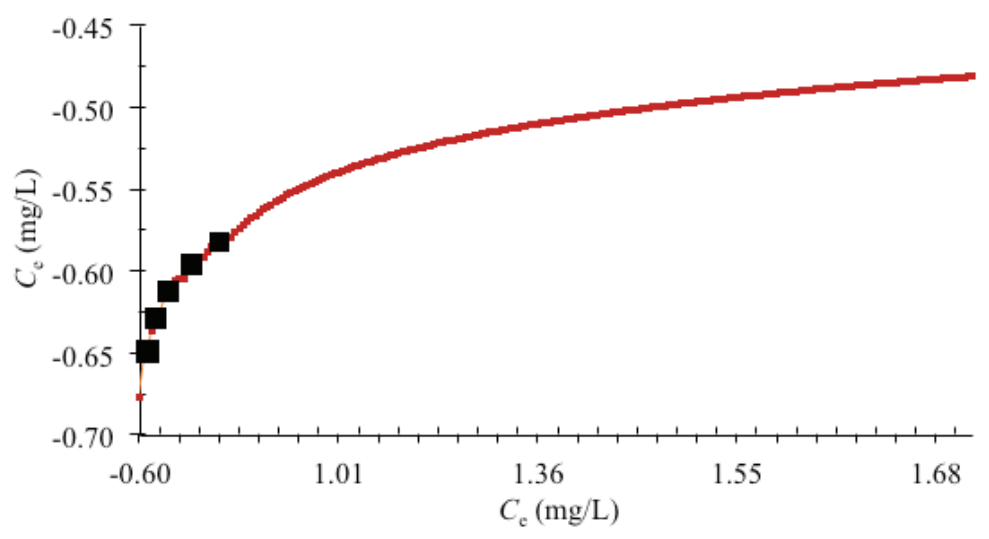

RAJAH 7. Graf model isoterma Freundlich bagi penjerapan MB oleh hidrogel B [2:1]

isoterma Freundlich pula digambarkan sebagai jerapan pada pemukaan heterogen yang juga terdapat pada bahan penyerap dengan satu andaian dibuat; tapak jerapan yang kuat akan dipenuhi terlebih dahulu dengan bahan terjerap dan kekuatan jerapan oleh bahan penyerap (hidrogel $\mathrm{B}[2: 1])$ akan berkurangan dengan bertambahnya darjah tapak jerapan yang dipenuhi dengan bahan terjerap. Keterterapan bagi setiap persamaan model isoterma diwajarkan dengan perbandingan koefisien kolerasi, $R_{2}$. Model isoterma Langmuir adalah seperti dalam (7):

$$
\frac{C_{\mathrm{e}}}{q_{\mathrm{e}}}=\frac{1}{Q_{\mathrm{o}}{ }^{b}}+\left(\frac{1}{q_{\mathrm{e}}}\right) C_{\mathrm{e}}
$$

dengan $C_{\mathrm{e}}$ adalah kepekatan MB pada keseimbangan; $q_{\mathrm{e}}$ adalah jumlah bahan terjerap yang dijerap per unit berat (gram) hidrogel (mg/g). $Q_{\mathrm{o}}$ dan $b$ adalah pemalar Langmuir iaitu kapasiti jerapan dan kadar jerapan. Apabila graf $C_{\mathrm{e}} / q_{\mathrm{e}}$ melawan $C_{\mathrm{e}}$ diplotkan, garis lurus (linear) terbentuk dengan kecerunannya diwakili dengan $\left(1 / Q_{\mathrm{e}}\right)$. Graf ini dapat ditunjukkan pada Rajah 8.

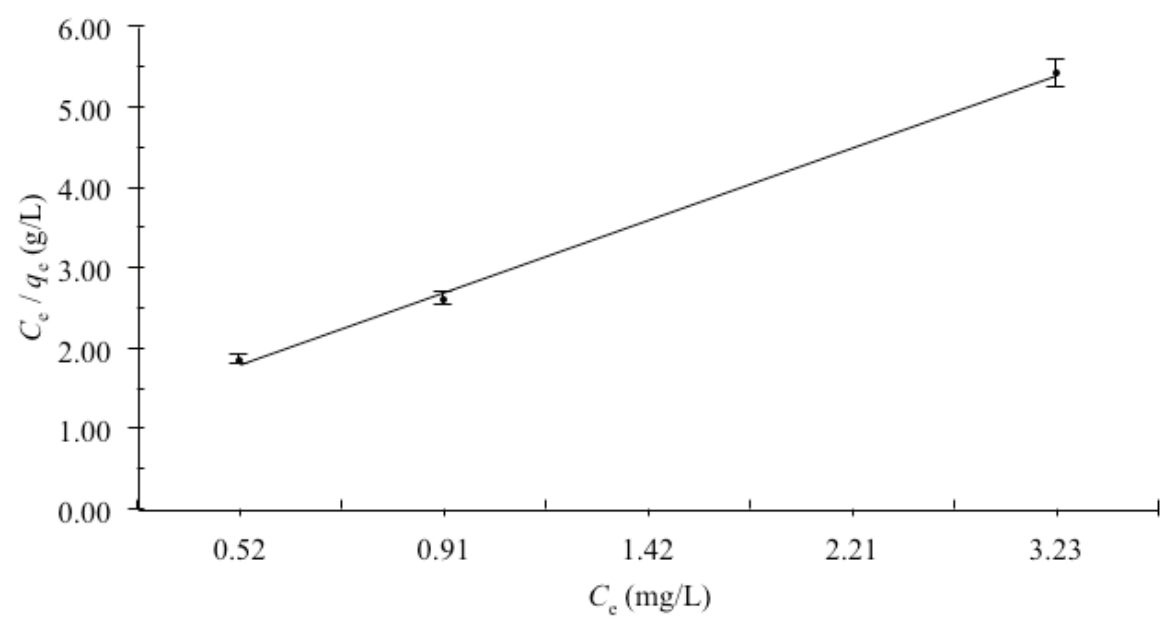

RAJAH 8. Graf linear $C_{\mathrm{e}} / q_{\mathrm{e}}$ melawan $C_{\mathrm{e}}$ (model isoterma Langmuir) bagi jerapan MB oleh hidrogel B [2:1] 
Pemalar Langmuir dihitung dan kesemua nilai pemalar ditunjukkan seperti dalam Jadual 2. Nilai pemalar ini membuktikan bahawa permukaan hidrogel $\mathrm{B}[2: 1]$ adalah homogen dan penjerapan MB ke atas hidrogel bersamaan dengan tenaga pengaktifan penjerapan yang terdapat pada hidrogel berkenaan. Sifat utama model isoterma Langmuir ini juga boleh diterjemahkan dengan parameter keseimbangan yang diwakili $R_{\mathrm{L}}$, berdasarkan (8):

$$
R_{\mathrm{L}}=\frac{1}{1+b C_{\mathrm{o}}}
$$

Sekiranya nilai $R_{\mathrm{L}}$ adalah lebih besar daripada nilai 1, model isoterma ini tidak boleh diterima pakai. Sekiranya $R_{\mathrm{L}}$ adalah bersamaan dengan nilai 1 , model isoterma ini adalah linear manakala nilai $0<R_{\mathrm{L}}<1$ menunjukkan model isoterma ini boleh diterima pakai. Jika $R_{\mathrm{L}}$ bersamaan dengan sifar, model isoterma ini tidak berbalik. Nilai $R_{\mathrm{L}}$ yang diperoleh daripada kajian ini adalah 0.13 , membuktikan bahawa isoterma ini boleh diterima-pakai. Jadual 2 menunjukkan perbandingan pemalar bagi model isoterma Langmuir dan Freundlich bagi jerapan MB oleh hidrogel $\mathrm{B}[2: 1]$.

JADUAL 2. Perbandingan pemalar bagi model isoterma Langmuir dan Freundlich bagi jerapan MB oleh hidrogel B [2:1]

Pemalar isoterma Langmuir dan Freundlich untuk bahan terjerap (MB)

Model Isoterma Langmuir

$\begin{array}{ccc}Q_{\mathrm{o}}(\mathrm{mg} / \mathrm{g}) & 1.11 & \\ b\left(\mathrm{mg}^{-1}\right) & 1.01 & \\ R^{2} & 0.9984 & \\ R_{\mathrm{L}} & 0.13 \quad>1 \text {, diterima-pakai }\end{array}$

Model Isoterma Freundlich $1 / n \quad 0.0765>1$, normal model isoterma Langmuir

$K_{\mathrm{F}}\left[(\mathrm{mg} / \mathrm{g})\left(\mathrm{mg}^{-1}\right)^{1 / n}\right] \quad 0.25$

Persamaan logaritma model isoterma Freundlich adalah seperti (9):

$$
\log q_{\mathrm{e}}=\log K_{\mathrm{F}}+\left(\frac{1}{n}\right) \log C_{\mathrm{e}}
$$

dengan $q_{\mathrm{e}}$ adalah jumlah jerapan pada keseimbangan (mg/g); $C_{\mathrm{e}}$ adalah kepekatan bahan terjerap MB; $K_{\mathrm{F}}$ dan $n$ adalah pemalar Freundlich. $K_{\mathrm{F}}$ adalah kapasiti penjerapan oleh hidrogel manakala $n$ mewakili kebolehan terima-pakai model isoterma Freundlich.

Selain itu, $K_{\mathrm{F}}$ juga adalah penjerapan atau koefisien penyebaran yang mewakili kuantiti MB yang dijerap oleh hidrogel untuk unit kepekatan pada keseimbangan. Kecerunan $(1 / n)$ pada graf, julat antara 0 hingga 1 adalah ukuran bagi kepekaan penjerapan atau keheterogenan permukaan. Nilai $1 / n$ yang persis kepada nilai 0 menunjukkan bahan penjerap mempunyai keheterogenan yang tinggi. Nilai $1 / n$ yang lebih rendah daripada 1 menunjukkan isoterma Langmuir yang normal, manakala nilai $1 / n$ yang lebih tinggi daripada 1 menunjukkan penjerapan yang ko-operatif. Rajah 9 menunjukkan graf $\log q_{\mathrm{e}}$ melawan $\log C_{\mathrm{e}}$ membentuk garis lurus dengan kecerunan $(1 / n)$ menunjukkan penjerapan MB oleh hidrogel B [2:1] mematuhi isoterma Freundlich.

Pemalar Freundlich juga dihitung dan ditunjukkan pada Jadual 2. Berdasarkan keputusan yang diperoleh dalam Jadual 2, perbandingan dapat diperhatikan sama ada data yang diperoleh daripada kajian ini mematuhi model isoterma Langmuir atau Freundlich. Hasilnya, $R^{2}$ bagi model Langmuir $\left(R^{2}=0.9984\right)$ lebih persis daripada $R^{2}$ daripada model Freundlich $\left(R^{2}=0.9954\right)$. Selain itu, nilai $1 / n(0.076)$ yang diperoleh daripada kajian ini membuktikan bahawa kepersisan data penjerapan ini boleh diterima pakai seperti yang dilaporkan oleh Bulut dan Aydın (2006) dan Fytianos et al. (2000). Menurut Hameed et al. (2007), penjerapan isoterma ini juga penting untuk menerangkan bagaimana interaksi molekul MB paling optimum yang telah dijerap oleh hidrogel yang mana bertindak sebagai bahan penyerap.

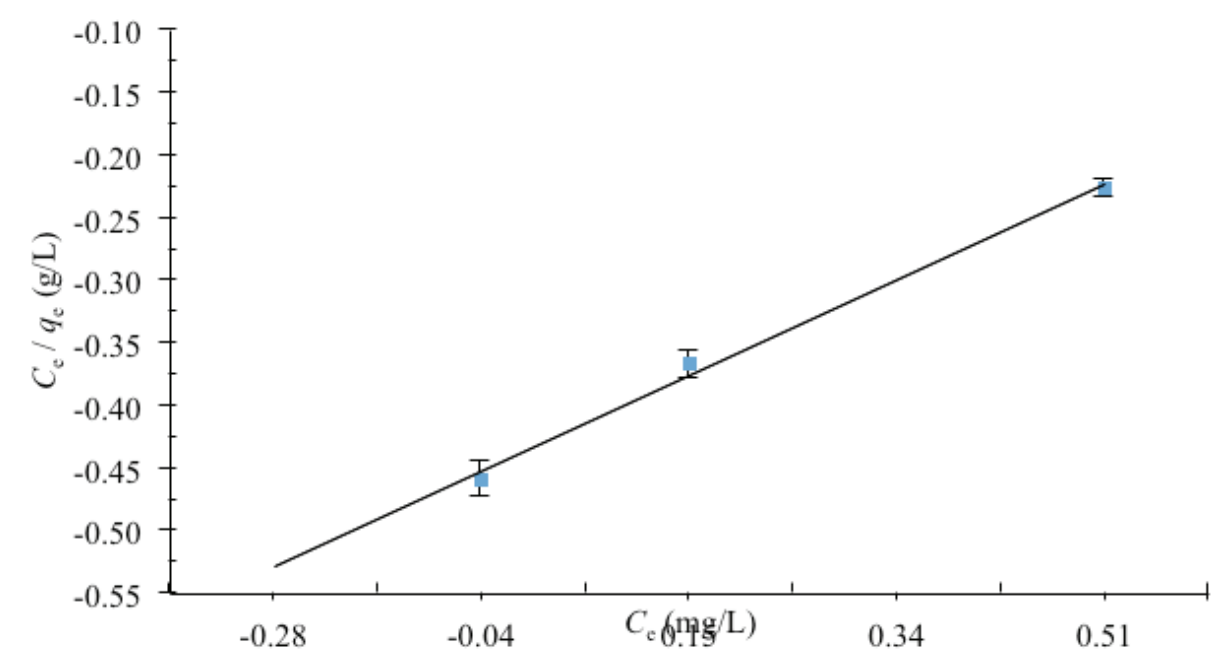

RAJAH 9. Graf linear $\log q_{\mathrm{e}}$ melawan $\log C_{\mathrm{e}}$ (model isoterma Freundlich) bagi jerapan MB oleh hidrogel B [2:1] 
Jerapan MB ke atas kesemua hidrogel adalah berdasarkan kepada pergerakan molekul MB sama ada ke atas permukaan hidrogel mahupun pergerakan molekul MB menembusi dinding hidrogel seterusnya membentuk interaksi yang kompleks dengan jaringan poliakrilik dalam hidrogel (Ofomaja 2007). Ini disokong oleh Olivera et al. (2016) yang telah mencadangkan bahawa selulosa dengan caj negatif yang tinggi membentuk ikatan yang stabil dengan pewarna caj positif melalui mekanisma interaksi elektrostatik antara pewarna dan selulosa-O- pada permukaan membran. Penjerapan MB ke atas jaringan hidrogel akan berlaku sehingga mencapai keseimbangan dinamik dan baki MB yang tinggal akan kekal dalam larutan (fasa cecair). Interaksi yang berlaku antara molekul MB dan jaringan poliakrilik dalam hidrogel sebenarnya bertanggungjawab ke atas kapasiti pertukaran kation pada jaringan hidrogel dan molekul MB seperti yang dilaporkan oleh Ho dan McKay (1999).

\section{KESIMPULAN}

Secara umumnya, sintesis hidrogel berasaskan NDC yang dicangkukkan dengan jaringan poliakrilik menggunakan kaedah sinaran gamma telah berjaya dihasilkan. Proses pencantuman poliakrilik ke atas NDC bertujuan untuk menghasilkan jaringan hidrogel yang berkeupayaan untuk menyingkir pewarna kationik daripada sisa air buangan industri. Ujian penjerapan MB menggunakan spektrofotometer (UV/VIS) telah dijalankan ke atas ketigatiga hidrogel ini. Secara umumnya, ketiga-tiga hidrogel menunjukkan prestasi yang baik dalam penjerapan $\mathrm{MB}$ dan hidrogel B [2:1] telah terbukti mempunyai kapasiti penjerapan MB paling tinggi berbanding hidrogel A [1:1] dan hidrogel $\mathrm{C}$ [3:1]. Keputusan menunjukkan penjerapan MB ke atas hidrogel B [2:1] mematuhi model kinetik tertib kedua-Pseudo. Ini kerana hidrogel B [2:1] mempunyai kebolehjerapan yang baik antara jaringan hidrogel yang besar.

\section{RUJUKAN}

Amin, M.C.I.M., Abadi, A.G. \& Katas, H. 2014. Purification, characterization and comparative studies of spray-dried bacterial cellulose microparticles. Carbohydrate Polymers 99: 180-189.

Amin, M.C.I.M., Ahmad, N., Halib, N. \& Ahmad, I. 2012. Synthesis and characterization of thermo- and $\mathrm{pH}$-responsive bacterial cellulose/acrylic acid hydrogels for drug delivery. Carbohydrate Polymers 88(2): 465-473.

Ashri, A. \& Lazim, A.M. 2014. A study on the effect of the concentration of $\mathrm{N}, \mathrm{N}$-methylenebisacrylamide and acrylic acid toward the properties of Dioscorea hispida-starch-based hydrogel. AIP Conference Proceedings 1614(1): 251-255.

Azizian, S. 2004. Kinetic models of sorption: A theoretical analysis. Journal of Colloid and Interface Science 276(1): 47-52.

Azizian, S. \& Fallah, R.N. 2010. A new empirical rate equation for adsorption kinetics at solid/solution interface. Applied Surface Science 256(17): 5153-5156.

Azman, I., Mutalib, A.S., Yusoff, S.F.M., Fazry, S., Noordin, A., Kumaran, M. \& Lazim, A.M. 2016. Novel discorea hispida starch based hydrogel and their beneficial useas disinfectant. Journal of Bioactive and Biocompatible Polymers 31(1): 42-59.

Azwan, M.L., Farahain, M., Siti, F.M.Y., Ahmad, I. \& Adil, H. 2013. Synthesis and characterization of ph sensitive hydrogel using extracted pectin from dragon fruit peel. Malaysian Journal of Analytical Sciences 17(3): 481-489.

Boo, W.P. \& Azwan, M.L. 2016. Synthesis and characterization of starch-based hydrogel by using gamma radiation technique. Malaysian Journal of Analytical Sciences 20(5): 1011-1019.

Bulut, Y. \& Aydın, H. 2006. A kinetics and thermodynamics study of methylene blue adsorption on wheat shells. Desalination 194: 259-267.

Dafader, N.C., Akter, T., Haque, M.E., Swapna, S.P., Islam, S. \& Huq, D. 2012. Effect of acrylic acid on the properties of polyvinylpyrrolidone hydrogel prepared by the application of gamma radiation. African Journal of Biotechnology 11(66): 13049-13057.

Fytianos, K., Voudrias, E. \& Kokkalis, E. 2000. Sorptiondesorption behaviour of 2,4-dichlorophenol by marine sediments. Chemosphere 40(1): 3-6.

Ghaedi, M., Nasab, A.G., Khodadoust, S., Rajabi, M. \& Azizian, S. 2014. Application of activated carbon as adsorbents for efficient removal of methylene blue: Kinetics and equilibrium study. Journal of Industrial and Engineering Chemistry 20(4): 2317-2324.

Hadi, H. \& Idayu, M.I. 2012. Impact of metal oxide nanoparticles on oral release properties of $\mathrm{pH}$-sensitive hydrogel nanocomposites. International Journal of Biological Macromolecules 50(5): 1334-1340.

Haerifar, M. \& Azizian, S. 2013. An exponential kinetic model for adsorption at solid/solution interface. Chemical Engineering Journal 215-216: 65-71.

Hameed, B.H., Din, A.T.M. \& Ahmad, A.L. 2007. Adsorption of methylene blue onto bamboo-based activated carbon: Kinetics and equilibrium studies. Journal of Hazardous Materials 141(3): 819-825.

Ho, Y.S. \& McKay, G. 1999. Pseudo-second order model for sorption processes. Process Biochemistry 34(5): 451-465.

Lee, S.C., Kwon, I.K. \& Park, K. 2013. Hydrogels for delivery of bioactive agents: A historical perspective. Advanced Drug Delivery Reviews 65: 17-20.

Liew, M., Rizafizah, O., Rozida, K., Amin, M.C.I.M. \& Azwan, M.L. 2015. Synthesis of hydrogel based on nata de coco and acrylic acid as co-monomer using free radical polymerization method. Malaysian Journal of Analytical Sciences 18(2): 299-305.

Ofomaja, A.E. 2007. Sorption dynamics and isotherm studies of methylene blue uptake on to palm kernel fibre. Chemical Engineering Journal 126(1): 35-43.

Olivera, S., Muralidhara, H.B., Venkatesh, K., Guna, K., Gopalakrishna, K. \& Kumar, Y.K. 2016. Potential applications of cellulose and chitosan nanoparticles/ composites in wastewater treatment: A review. Carbohydrate Polymers 153: 600-618.

Sajab, M.S., Chia, C.H., Zakaria, S. \& Khiew, P.S. 2013. Cationic and anionic modifications of oil palm empty fruit bunch fibers for the removal of dyes from aqueous solutions. Bioresour. Technol. 128: 571-577.

Sun, X.F., Liu, B., Jing, Z. \& Wang, H. 2015. Preparation and adsorption property of xylan/ poly(acrylic acid) magnetic nanocomposite hydrogel adsorbent. Carbohydrate Polymers 118: 16-23. 
Zhou, C., Lee, S., Dooley, K. \& Wu, Q. 2013. A facile approach to fabricate porous nanocomposite gels based on partially hydrolyzed polyacrylamide and cellulose nanocrystals for adsorbing methylene blue at low concentrations. Journal of Hazardous Materials 263(Part 2): 334-341.

Zhou, Y., Fu, S., Liu, H., Yang, S. \& Zhan, H. 2011. Removal of methylene blue dyes from wastewater using cellulose-based superadsorbent hydrogels. Polymer Engineering \& Science 51(12): 2417-2424.
Pusat Pengajian Sains Kimia \& Teknologi Makanan

Fakulti Sains \& Teknologi

Universiti Kebangsaan Malaysia

43600 Bangi, Selangor Darul Ehsan Malaysia

*Pengarang untuk surat-menyurat; email: azwanlazim@ukm. edu.my

Diserahkan: 22 Jun 2017

Diterima: 26 Oktober 2017 
